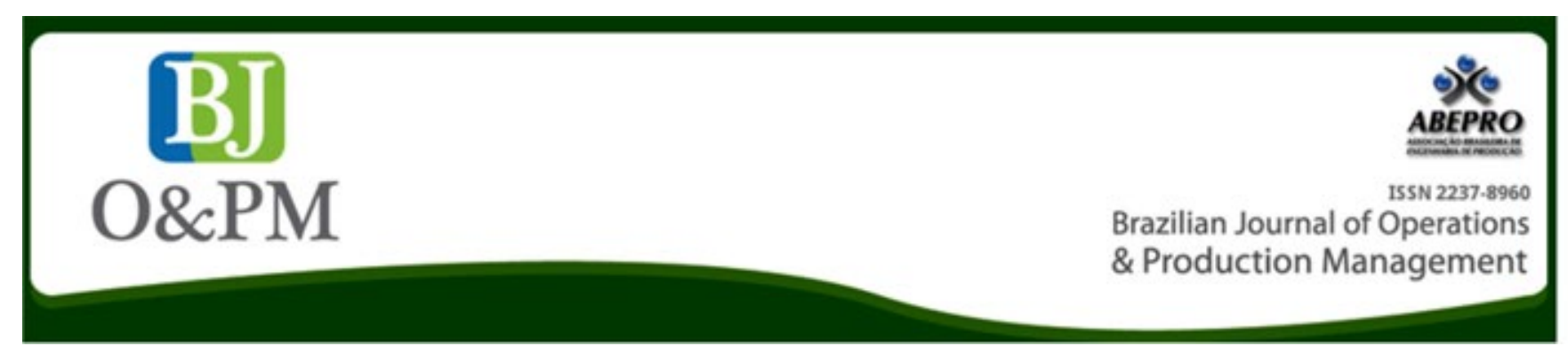

\title{
INTERDISCIPLINARITY IN HIGHER EDUCATION: A CROSS-SECTIONAL ANALYSIS OF THE LITERATURE IN THE PERIOD 2014-2018
}

\section{Bernardo Vitor de Souza Marins \\ bernardosouza@id.uff.br \\ Fluminense Federal University - \\ UFF, Niterói, Rio de Janeiro, Brazil \\ Hellen Costa Ramos \\ hellencost@gmail.com \\ Secretaria de Estado da Educação \\ - SEEDUC, Rio de Janeiro, Rio de \\ Janeiro, Brazil}

\section{Geraldo de Souza Ferreira geraldoferreira@vm.uff.br Fluminense Federal University - UFF, Niterói, Rio de Janeiro, Brazil}

\section{Stella Regina Reis Costa}

stellare@ig.com.br

Fluminense Federal University -

UFF, Niterói, Rio de Janeiro, Brazil

\section{Helder Gomes Costa}

heldergc@id.uff.br

Fluminense Federal University -

UFF, Niterói, Rio de Janeiro, Brazil

\begin{abstract}
Goal: The growing complexity of problems induces the use of multi- and interdisciplinary approaches in their solution. This situation occurs in a number of fields, including in the field of Education. The results of research from the interdisciplinary point of view in Education are presented in several journals, addressing different subjects, which prevents a holistic view on the development of this area. In order to fill this gap, this article aims to study interdisciplinarity in education in order to understand how the concept of interdisciplinarity has been applied in this area.

Design / Methodology / Approach: It consists of a bibliographical survey, with articles indexed in the SCOPUS database. The selection of articles was limited to a transversal research in the literature from 2014 to 2018, using the following keywords: interdisciplinarity and higher education.

Limitations of the investigation: Through the methodology used, 60 articles were selected.

Results: Few articles were related to interdisciplinary practices, demonstrating the need for research to cover this gap.

Practical implications: Although the subject began in the 1970s, there is still much to be researched regarding interdisciplinarity in education, to allow a better dissemination and practice thereof, so that students have a systemic view of current complexity.

Originality / Value: The study points out a gap in the literature, and the quantitative results suggest that there is a greater deficiency of works directed to the application of the interdisciplinary approach in the development of this aspect for the improvement of society.
\end{abstract}

Keywords: Interdisciplinarity; Education; Interdisciplinarity in Education; Interdisciplinary subjects. 
Brazilian Journal of Operations \& Production Management

Volume 16, Número 1, 2019, pp. 113-125

DOI: 10.14488/BJOPM.2019.v16.n1.a11

\section{INTRODUCTION}

From the contemporaneity, complex problems that should be discussed in an unconventional, strictly disciplinary way arise. It is thus necessary that the different fields of knowledge dialogue and produce new forms of knowledge. According to Hannon et al. (2018), the focus on complex problems brings the need to have interdisciplinary curricula, beyond the limit of the subjects, to allow a better understanding.

According to Clark et Wallace (2015), knowledge is fragmented in its organization, classification, production and use in academia, professions, and society. A practical conceptualization of interdisciplinarity in the interests of integration is necessary to address the multiple perspectives, epistemologies and fragmentation inherent in these problems.

Interdisciplinarity, conceived in its etymological definition, is used in an overly broad sense. The definition of interdisciplinary implies in the relations between two or more disciplines or branches of knowledge, or something that is common to two or more disciplines (Houaiss, 2017).

Barth et Michelsen (2013) note that sustainability comprises a concept that not only influences educational practices, but also suggests disciplinary contributions to foster inter and transdisciplinary research in the discourse of sustainability. The question remains as to how and to what extent educational science in particular can contribute to the science of sustainability in terms of an "inside-out" approach.

In this context, the question that emerges from the research is "what is the frontier of knowledge within the Interdisciplinarity and Higher Education interface?" Thus, the aim of this study is to carry out a cross-sectional bibliographic study on interdisciplinarity in education in the period 20142018 , in order to understand how the concept of interdisciplinarity has been applied in this field today. To achieve this goal, the following steps were taken: a) bibliographic research aiming to select the works in the last 5 years; $b$ ) analysis of selected articles, seeking to identify the subjects of the frontier of knowledge; and c) identification of the subjects cited by each of the authors.

\section{CONTEXT OF INTERDISCIPLINARITY}

Interdisciplinarity arises with the urgency of concern for the environment, and disciplinary issues are not enough to solve it. According to Weidner (1973), "interdisciplinarity and, in fact, all other forms of innovation, must be viewed from the standpoint of entire educational systems, thereby allowing the challenges to be faced."
Zverev (1975) believes that interdisciplinarity should be taken to the educational subject, reflecting its subordination to the structure of the study of school education, developed on the basis of an analysis of scientific knowledge.

In the analysis of the recent literature, interdisciplinarity is directly related to sustainability, and this can be studied at various educational levels. Annan-Diab et al. (2017) proposes that "interdisciplinarity should be applied to MBA students from graduate courses of different backgrounds," considering interdisciplinary education for sustainable development, where students should be encouraged to combine knowledge of different disciplines, in order to advance in understanding and sustainable development issues.

In the view of Klein et al. (2017), "interdisciplinarity and collaboration are key words for change in the $21^{\text {st }}$ century. Both, however, face challenges across the academic system, from administrative policies and budget formulas to disciplinary research and education cultures."

With so much specialization of the disciplines, the search for interdisciplinarity falls in the complex field. Tarrant et Thiele (2016), believes that "interdisciplinarity needs a huge effort to be achieved" and there is little discussed in the literature regarding practices and the way it occurs. According to Choi et al. (2006), "interdisciplinarity analyzes, synthesizes and harmonizes the links between disciplines in a coordinated and coherent whole."

In the perspective of Morillo et al. (2003), "interdisciplinarity is considered the best way to tackle practical research topics, and studies on interdisciplinarity, from every possible perspective, are increasingly required," for a better understanding of the complex and what may be required for sustainable development. According to Steiner et Posch (2006), "traditional unidirectional educational processes are of very limited use for the education of sustainable development." The systemic view becomes important in this context, and the authors further corroborate that "mutual learning based on real-world cases requires an interdisciplinary point of view." The resolution of the complex sustainable development dilemma requires other attributes, such as creative ability, social skills, and specific communication skills to address dynamic transformation, and these lessons should occur in the classroom.

Universities play a key role in this process, and improving interdisciplinarity becomes a strategic goal at almost all levels of education according to Ferrer-Balas et al. (2008). According to Richter et Paretti (2009), "educators do not yet have rigorous research on learning barriers, outcomes, and concrete interventions to support this interdisciplinary development." 
Fiore (2008) considers teamwork important to improve research in the interdisciplinary field and the practice of science. According to Rhoten et Pfirman (2007), "in the United States, funding agencies fund interdisciplinary research and universities promote the expansion of interdisciplinary research." Interdisciplinarity is directly linked to sustainable issues, according to Yarime et al. (2012): "As sustainability issues span across multiple academic disciplines, from the natural sciences to the social and human sciences, interdisciplinarity has become a core idea for mastering the science of sustainability." Gasevic et al. (2014) reinforce that the scarcity of the subject of educational technological innovation could be a worrying sign of the fragmentation of research and the need to increase efforts to promote interdisciplinarity.

According to Bromham et al. (2016), "interdisciplinary research is widely considered a greenhouse for innovation, and the only plausible approach to complex problems." The problem of this subject is the issue of the financing of interdisciplinary studies.

\section{Interdisciplinarity in Education}

According to Klassen (2018), in order to design an interdisciplinary education, some variables are necessary, such as "the choice of the problem, the level of interaction between different disciplines, and the constructive alignment." Leydesdorff et al. (2018), however, state it is difficult to operationalize interdisciplinarity in the absence of a definition of the disciplines.

Correia et Souza (2018) conceptualize interdisciplinarity as a guiding principle for theories and methodologies in several fields of knowledge. Notwithstanding, interdisciplinary research involves other aspects such as politics, pedagogy and epistemology.

Raynaut (2014) notes that interdisciplinarity arises in the context of understanding contemporary issues, beyond disciplinary boundaries, in order to understand the complexity of current problems, focusing on methodological issues.

According to Raynaut (2011), interdisciplinarity is a process of dialogue between disciplines that are established in their theoretical and methodological identity, but which respect the knowledge produced by others, acknowledging their own limits, thereby confronting disciplinary fields to feed a core problem without requiring distancing itself from its own questions. There should not be a hierarchy between the disciplines - there ought to be a mutual feeding to generate new questions, approaches, and results.

The university continues to be a merely expository environment, and it is necessary for educators to be aware of the theoretical purposes that justify the need for interdisciplinary action. It is not possible to develop an understanding and complex thinking only with the juxtaposition of teachers in the classroom. It is necessary to rescue the importance of the "other" in the construction of knowledge without ignoring the social changes, understanding the current reality. Further, there should be redundancy in the sense of promoting the interaction of the individuals with the aim of exchanging information among the teachers to create an adequate and comprehensive curriculum (Kern et al., 2011).

\section{METHODOLOGY}

The bibliographic search was carried out in the Scopus indexed database, on October 20, 2018, using the following keywords: TITLE-ABS-KEY (("interdisciplinarity AND "higher education")) AND (LIMIT-TO (DOCTYPE, "ar")) OR LIMIT-TO (DOCTYPE, "re") OR LIMIT-TO (DOCTYPE, “ip")) AND (LIMIT-TO (SRCTYPE, "j")) AND (LIMIT-TO (PUBYEAR, 2018)) OR LIMIT-TO (PUBYEAR, 2017) OR LIMIT-TO (PUBYEAR, 2016) OR LIMIT-TO (PUBYEAR, 2015) OR LIMIT-TO (PUBYEAR, 2014)), limited to a study that is characterized as cross-sectional, the period of time for the search in the portal database, in the last 5 years, being motivated by the aspect of the unpublished contribution of the identified studies. After the search, 108 articles were found. The selection considered articles, reviews, and press articles. In the filter, 108 articles were analyzed considering their adhesion to the title and the abstract, with 60 remaining in the selection of articles for the composition of the "initial core," based on the bibliometric model used by Freitas (2017). Thus, the steps of the Methodology are described in Figure 1 below:

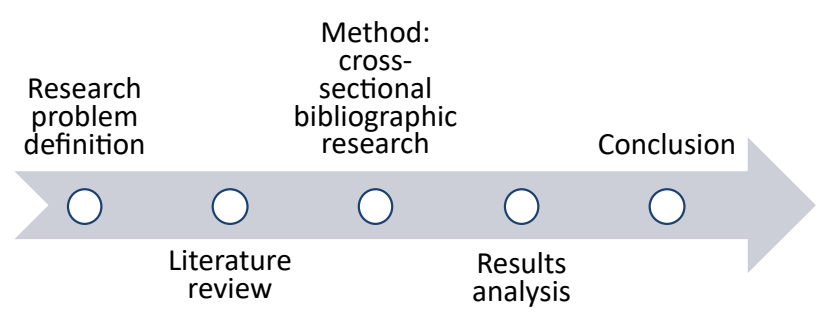

Figure 1. Research steps - Authors' own work (2018).

Figure 1 represents the steps taken by the systematic research. The research problem was defined. Following that, we performed the literature review, defining the interdisciplinarity and its context, as well as Interdisciplinarity in Education. The method consisted of a bibliographic and cross-sectional research in the period 2014-2018. Following that, it was performed the analysis of the results, in which 10 subjects were addressed by the authors. Finally, the conclusion was developed. 


\section{CRITICAL ANALYSIS OF THE ARTICLES}

With the articles selected as the "starting core," an analysis of the abstracts was carried out to identify the articles that corresponded most to the initial idea of the search: to verify how interdisciplinarity is inserted in education and what the authors' understanding is regarding the meaning of interdisciplinarity and its importance. Thus, the analysis of the most relevant abstracts is presented in Chart 1 below.

Based on the analysis of the abstracts, the 10 subjects most frequently addressed by the authors regarding the interface between interdisciplinarity and higher education are presented in Chart 2. The following were considered: $S_{1}=$ Study of Complex Problems (Related to studies of complex problems); $\mathrm{S}_{2}=$ Sustainable Issues (Relationship with sustainable development); $S_{3}=$ Interdisciplinarity as a Method (definition of applied Interdisciplinarity as a teaching method); $\mathrm{S}_{4}$ $=$ Interdisciplinary Practices (the authors approach interdisciplinarity as a teaching practice); $S_{5}=$ Curricular Questions (change in the curriculum aiming at achieving interdisciplinarity); $\mathrm{S}_{6}=$ Contemporary Discourse (Modern Problems); $\mathrm{S}_{7}=$ Interdisciplinarity for Innovation (Interdisciplinarity for technological advancement); $\mathrm{S} 8$ = Interdisciplinarity in the Improvement of Skills and Competencies (Interdisciplinarity in the improvement of skills and competencies); $S_{9}=$ Interdisciplinary Approach (defining Interdisciplinarity as an approach); and $\mathrm{S}_{10}=$ Other (none of the criteria mentioned above were identified).

Chart 1. Concept of interdisciplinarity in Education - Authors' own work (2018).

\begin{tabular}{|c|c|c|}
\hline YEAR & AUTHORS & CONCEPTS \\
\hline 2018 & Hannon et al. & $\begin{array}{l}2018 \text { Hannon et al. It conceptualizes interdisciplinarity as a contemporary movement of curricular } \\
\text { change, with the focus on breaking down the disciplinary boundaries, from the need } \\
\text { to study the complex problems. }\end{array}$ \\
\hline 2018 & Murray & $\begin{array}{l}\text { It argues that student-led actions through multi-stakeholder collaboration, interdisciplinarity and col- } \\
\text { lective action have an influence on sustainability in higher education, but that research has not made it } \\
\text { possible to see to what extent this occurs in influencing institutional change, best practice, } \\
\text { and intersections with social justice more broadly. }\end{array}$ \\
\hline 2018 & Schäfke et al. & $\begin{array}{l}\text { The interdisciplinary approach in law education has been advocated. Nevertheless, there is little } \\
\text { evidence in terms of how this form of teaching can influence the relationship with other disciplines. Em- } \\
\text { pirical evidence demonstrates that the adoption of interdisciplinary teaching is related to their previous } \\
\text { higher education, socialization in research, and multidisciplinary environments. }\end{array}$ \\
\hline 2018 & Longhurst et al. & $\begin{array}{l}\text { For authors to critically reflect on the curriculum enhancement program led by them, they would have } \\
\text { acted differently to increase students' opportunities for interdisciplinarity in teaching and research. It is } \\
\text { of the utmost importance that students be able to study issues based on interdisciplinary perspectives } \\
\text { and to have maximum flexibility in their grades, thus ensuring that their choices are purposeful. In addi- } \\
\text { tion, it is important to facilitate the interactions of the deans, academic directors, and other college staff } \\
\text { so that everyone has the same goal of collaboration and do not act independently. }\end{array}$ \\
\hline 2018 & Pereira et al. & $\begin{array}{c}\text { According to the authors, interdisciplinarity would collaborate in professional training, improvement to } \\
\text { the teamwork, and greater ability to address subjects related to health. }\end{array}$ \\
\hline 2018 & Khoo et al. & $\begin{array}{l}\text { According to the authors, interdisciplinarity and transdisciplinarity are methodological approaches to } \\
\text { address complex problems. }\end{array}$ \\
\hline 2018 & Ülkü et al. & $\begin{array}{l}\text { Interdisciplinarity acts in the solution of contemporary and complex problems, working in the integration } \\
\text { of the disciplines, and collaborating in the exchange of new knowledge. With this, it would act in the } \\
\text { retention of the undergraduate student, through improved curricula. }\end{array}$ \\
\hline 2018 & Vienni et al. & $\begin{array}{l}\text { The authors emphasize that universities are conducive environments for interdisciplinary action, as they } \\
\text { have tradition and spaces for experimentation. }\end{array}$ \\
\hline 2018 & Sparke, M. & $\begin{array}{l}\text { The author reflects on the challenge faced in interdisciplinary writing, to appeal } \\
\text { to a disciplinary audience. }\end{array}$ \\
\hline 2018 & Sclater and Lally & $\begin{array}{l}\text { The authors cite interdisciplinarity as an interlacing of the disciplines and, with that, } \\
\text { view higher education under a new approach. }\end{array}$ \\
\hline 2018 & Milić et al. & Based on an interdisciplinary knowledge, there is an opportunity to improve skills and knowledge. \\
\hline 2018 & $\begin{array}{l}\text { Molderez and } \\
\text { Fonseca }\end{array}$ & $\begin{array}{l}\text { Interdisciplinary education, combined with diverse activities, appears as an opportunity to overcome the } \\
\text { barrier for the acquisition of sustainable skills. }\end{array}$ \\
\hline 2018 & Haapakorpi & $\begin{array}{c}\text { Higher education is disciplinary, but the student, upon reaching the labor market, encounters multi- or } \\
\text { interdisciplinary issues. }\end{array}$ \\
\hline
\end{tabular}




\begin{tabular}{|c|c|c|}
\hline 2018 & Mossman & $\begin{array}{l}\text { Disciplinary educational centers should encourage interdisciplinarity as the challenge of addressing com- } \\
\text { plex issues with sustainable issues. }\end{array}$ \\
\hline 2018 & $\begin{array}{l}\text { Chernetsova } \\
\text { et al. }\end{array}$ & $\begin{array}{l}\text { The author notes that, in modern universities in Russia, interdisciplinarity and complexity are the main } \\
\text { principles that underlie the proposed integrative approach used in higher education. }\end{array}$ \\
\hline 2018 & Ouellet et al. & $\begin{array}{l}\text { According to the authors, the interdisciplinary dialogue is promoted based on the need to understand } \\
\text { the study of sustainability. }\end{array}$ \\
\hline 2018 & Nanni et al. & $\begin{array}{c}\text { The authors analyze the changes in interdisciplinary practices, with the adoption of computational } \\
\text { approaches. }\end{array}$ \\
\hline 2018 & $\begin{array}{l}\text { Grierson and } \\
\text { Munro }\end{array}$ & $\begin{array}{l}\text { The authors discuss the relationship between sustainable development and interdisciplinarity in distance } \\
\text { Higher Education. }\end{array}$ \\
\hline 2017 & Donina et al. & $\begin{array}{l}\text { Interdisciplinary research is critical to meeting contemporary challenges. In this sense, interdisciplinarity } \\
\text { has become prominent in political discourse for science and Higher Education. }\end{array}$ \\
\hline 2017 & $\begin{array}{l}\text { Power and } \\
\text { Handley }\end{array}$ & $\begin{array}{l}\text { The complex problems created by global society require moving beyond disciplinary boundaries, and } \\
\text { interdisciplinary practices emerge as facilitators for solving these problems. }\end{array}$ \\
\hline 2017 & Self and Baek & $\begin{array}{c}\text { Interdisciplinarity arises to offer skills and competencies, thereby reinforcing the need to provide an } \\
\text { interdisciplinary curriculum with interdisciplinary experiences. }\end{array}$ \\
\hline 2017 & $\begin{array}{l}\text { Tarrant and } \\
\text { Thiele }\end{array}$ & $\begin{array}{l}\text { Interdisciplinarity is a challenge for achieving integrative knowledge in order to solve complex problems } \\
\text { in the field of sustainability studies. }\end{array}$ \\
\hline 2017 & $\begin{array}{l}\text { Knewstubb and } \\
\text { Nicholas }\end{array}$ & $\begin{array}{l}\text { According to the authors, the interdisciplinary conceptual model contributes to exploring the relation- } \\
\text { ship between teaching and learning as a methodological approach. }\end{array}$ \\
\hline 2017 & Brooks & $\begin{array}{l}\text { Contemporary problems can best be approached with broadly trained specialists who can think, imagine } \\
\text { and solve problems beyond academic disciplinary boundaries. }\end{array}$ \\
\hline 2017 & Buekers & $\begin{array}{l}\text { Interdisciplinarity as an approach can be used to explain how elite athletes deal with the complex nature } \\
\text { of sport skills. }\end{array}$ \\
\hline 2017 & Macuch and Dal & $\begin{array}{l}\text { The authors address interdisciplinarity as an important methodology, being a facilitator in understanding } \\
\text { concepts related to learning. }\end{array}$ \\
\hline 2017 & $\begin{array}{l}\text { Brudermann } \\
\text { et al. }\end{array}$ & $\begin{array}{l}\text { According to the authors, the interdisciplinary approach arises for a better understanding of environ- } \\
\text { mental and social issues, with the aim of promoting sustainable development. }\end{array}$ \\
\hline 2017 & Holt et al. & $\begin{array}{l}\text { There is a growing need for interdisciplinary education, based on socio-environmental issues that go } \\
\text { beyond disciplinary boundaries. }\end{array}$ \\
\hline 2017 & Pinto et al. & $\begin{array}{l}\text { The authors believe that the interdisciplinary approach broadens the possibility of complementing the } \\
\text { gaps left by disciplinary and multidisciplinary approaches. }\end{array}$ \\
\hline 2016 & Ribeiro & $\begin{array}{l}\text { The author notes that having a network of researchers and strong links are positively related to interdis- } \\
\text { ciplinarity. }\end{array}$ \\
\hline 2016 & $\begin{array}{l}\text { Shandas and } \\
\text { Brown }\end{array}$ & $\begin{array}{l}\text { Interdisciplinarity is an educational and research paradigm that emerges to address complex problems } \\
\text { beyond disciplinary boundaries. Interdisciplinarity presents a practical approach to dealing with contem- } \\
\text { porary challenges. }\end{array}$ \\
\hline 2016 & Kaittani et al. & The authors analyze interdisciplinarity as a method used in teaching and learning. \\
\hline 2016 & $\begin{array}{l}\text { Toassi and } \\
\text { Lewgoy }\end{array}$ & They cite interdisciplinarity as an innovative teaching-learning practice, encouraging curricular change. \\
\hline 2016 & Causgrove et al. & $\begin{array}{l}\text { Complex problems require a combination of disciplines for the best understanding, and for this to occur, } \\
\text { researchers must be open to listening to one another. }\end{array}$ \\
\hline 2016 & Szostak & It addresses interdisciplinarity as a methodology. \\
\hline 2016 & Wood et al. & Interdisciplinarity was established with a key principle and the challenge of understanding sustainability. \\
\hline 2016 & Widener et al. & $\begin{array}{l}\text { The authors consider curricular change and build new interdisciplinary links to teach the concepts of } \\
\text { sustainability. }\end{array}$ \\
\hline 2015 & Peterson & Higher education is improved based on interdisciplinary thinking. \\
\hline 2015 & $\begin{array}{l}\text { Cárdenas-Ro- } \\
\text { drigues et al. }\end{array}$ & The authors cite innovative educational changes based on the principles of interdisciplinarity. \\
\hline 2015 & Alexei & $\begin{array}{l}\text { The author cites interdisciplinarity and curricular customization as an interactive teaching strategy aimed } \\
\text { at developing learning skills and abilities. }\end{array}$ \\
\hline 2015 & Monk et al. & $\begin{array}{l}\text { The authors cite that technology and curriculums allow the creation of research that is not limited by } \\
\text { disciplines, but rather by interdisciplinary interactions. }\end{array}$ \\
\hline
\end{tabular}




\begin{tabular}{|c|c|c|}
\hline 2015 & Holley & $\begin{array}{c}\text { It emphasizes the challenge of creating innovative, collaborative and interdisciplinary knowledge in } \\
\text { response to enormous social demands. }\end{array}$ \\
\hline 2015 & Miles & $\begin{array}{l}\text { Collaborative teaching and learning, with the technological tools, helps to foster innovation and interdis- } \\
\text { ciplinary work. }\end{array}$ \\
\hline 2015 & $\begin{array}{l}\text { Scimeca and } \\
\text { Labaree }\end{array}$ & $\begin{array}{l}\text { According to the authors, going beyond disciplinary boundaries may be an effective way to understand } \\
\text { complex problems, but little is known about interdisciplinary practices. }\end{array}$ \\
\hline 2015 & Engerman & $\begin{array}{l}\text { Academically interdisciplinarity is highlighted for its ability to deliver important results in research and } \\
\text { contribute to innovation. }\end{array}$ \\
\hline 2015 & Lygo-Baker et al. & $\begin{array}{l}\text { Interdisciplinarity is inserted as a dynamic that can serve as the basis for a new program of support for } \\
\text { clinical teaching. }\end{array}$ \\
\hline 2015 & Vasconcelos & $\begin{array}{l}\text { The author indicates that the graduate program in nutrition in Brazil, due to its complexity, breadth, } \\
\text { epistemology and heterogeneous methodology, requires the search for interdisciplinarity. }\end{array}$ \\
\hline 2014 & Ventura and Lins & $\begin{array}{l}\text { They consider that interdisciplinarity, as well as multidisciplinarity and transdisciplinarity, have become } \\
\text { criteria for institutional evaluation in various countries. }\end{array}$ \\
\hline 2014 & McCulloch & $\begin{array}{c}\text { Research is addressed in an interdisciplinary way regarding teaching and social practices, overlapping the } \\
\text { research model studied in a multidisciplinary way. }\end{array}$ \\
\hline 2014 & $\begin{array}{l}\text { Bursztyn and } \\
\text { Drummond }\end{array}$ & $\begin{array}{l}\text { The authors consider that interdisciplinarity should be treated in an integrated way with disciplinarity, } \\
\text { without considered opposites. }\end{array}$ \\
\hline 2014 & Bossio et al. & The authors provide a map for successful interdisciplinary collaboration. \\
\hline 2014 & Fonsêca et al. & $\begin{array}{l}\text { The authors consider that education through work is capable of assisting in the training process, and that } \\
\text { one of its advantages is the establishment of interdisciplinarity in the education process. }\end{array}$ \\
\hline 2014 & Cesco et al. & $\begin{array}{l}\text { Interdisciplinarity is especially important in graduate education. The authors examine their construction } \\
\text { and institutionalization in addition to the intended and/or unforeseen outcomes in a graduate program. }\end{array}$ \\
\hline 2014 & Strengers & $\begin{array}{l}\text { The authors stress that tensions in the doctoral course may overwhelm the doctoral students. They em- } \\
\text { phasize that there is not always a need for interdisciplinarity to solve real world problems. }\end{array}$ \\
\hline 2014 & $\begin{array}{l}\text { Oliva-Figueroa } \\
\text { et al. }\end{array}$ & $\begin{array}{l}\text { The scarcity and practical constraints of a flexible curriculum restrict the denser interdisciplinary and } \\
\text { transdisciplinary discourses in higher education. }\end{array}$ \\
\hline 2014 & Macdonnell & The author addresses interdisciplinarity as a dimension of emancipatory nursing. \\
\hline 2014 & Lee & $\begin{array}{l}\text { The author notes that interdisciplinarity has been used in higher education as a response to the need for } \\
\text { training of generalists and non-specialists. }\end{array}$ \\
\hline 2014 & Mobley et al. & $\begin{array}{l}\text { The authors address the teaching of sustainability and biocomplexity in the interdisciplinary perspective. } \\
\text { The innovative format and pedagogical approach can be employed in other disciplines to promote an } \\
\text { understanding of complex environmental issues. }\end{array}$ \\
\hline 2014 & Balon & $\begin{array}{l}\text { The author addresses the disappearance of postmodernism based on debates and perspectives for } \\
\text { interdisciplinarity. }\end{array}$ \\
\hline 2014 & Duda & Interdisciplinarity is guided by a methodology. \\
\hline
\end{tabular}

Chart 2. Analysis of the subjects covered - Authors' own work (2018).

\begin{tabular}{|c|c|c|c|c|c|c|c|c|c|c|}
\hline Authors / Subjects & S1 & S2 & S3 & S4 & S5 & S6 & S7 & S8 & S9 & S10 \\
\hline Hannon et al. (2018) & $\mathrm{x}$ & & & & $\mathrm{x}$ & $x$ & & & & \\
\hline Murray (2018) & & $x$ & & $x$ & & & & & & \\
\hline Schäfke et al. (2018) & & & & & & & & & $x$ & \\
\hline Longhurst et al. (2018) & & & & & $x$ & & & & & \\
\hline Pereira et al.(2018) & & & & & & & & $x$ & & \\
\hline Khoo et al. (2018) & $x$ & & $\mathrm{X}$ & & & & & & & \\
\hline Ülkü et al. (2018) & $x$ & & & & $\mathrm{X}$ & $\mathrm{X}$ & & & & \\
\hline Vienni et al. (2018) & & & & $x$ & & & & & & \\
\hline Sparke, M. (2018) & & & & & & & & & & $\mathrm{X}$ \\
\hline Sclater and Lally (2018) & & & & & & & & & $x$ & \\
\hline Milić et al. (2018) & & & & & & & & $x$ & & \\
\hline olderez and Fonseca (2018) & & $X$ & & $X$ & & & & $x$ & & \\
\hline
\end{tabular}




\begin{tabular}{|c|c|c|c|c|c|c|c|c|c|c|}
\hline Haapakorpi (2018) & & & & & & & & & & $x$ \\
\hline Mossman (2018) & $x$ & $x$ & & & & & & & & \\
\hline Chernetsova et al. (2018) & $x$ & & & & & & & & & \\
\hline Ouellet et al. (2018) & & $x$ & & & & & & & & \\
\hline Nanni et al. (2018) & & & & $x$ & & & & & & \\
\hline Grierson and Munro (2018) & & $x$ & & & & & & & & \\
\hline Donina et al.(2017) & & & & & & $x$ & & & & \\
\hline Power and Handley (2017) & $x$ & & & $x$ & & & & & & \\
\hline Self and Baek (2017) & & & & & $x$ & & & $x$ & & \\
\hline Tarrant and Thiele (2017) & $x$ & $x$ & & & & & & & & \\
\hline Knewstubb and Nicholas (2017) & & & $x$ & & & & & & & \\
\hline Brooks (2017) & & & & & & $\mathrm{x}$ & & & & \\
\hline Buekers (2017) & $\mathrm{x}$ & & & & & & & $x$ & $\mathrm{x}$ & \\
\hline Macuch and Dal (2017) & & & $\mathrm{X}$ & & & & & & & \\
\hline Brudermann et al. (2017) & & $\mathrm{x}$ & & & & & & & $x$ & \\
\hline Holt et al. (2017) & & $x$ & & & & & & & & \\
\hline Pinto et al. (2017) & & & & & & & & & $x$ & \\
\hline Ribeiro (2016) & & & & & & & & & & $\mathrm{x}$ \\
\hline Shandas and Brown (2016) & $x$ & & & $x$ & & $x$ & & & $x$ & \\
\hline Kaittani et al. (2016) & & & $\mathrm{X}$ & & & & & & & \\
\hline Toassi and Lewgoy (2016) & & & & $x$ & $\mathrm{x}$ & & & & & \\
\hline Causgrove (2016) & $x$ & & & & & & & & & \\
\hline Szostak (2016) & & & $\mathrm{x}$ & & & & & & & \\
\hline Wood et al. (2016) & & $x$ & & & & & & & & \\
\hline Widener et al. (2016) & & $x$ & & & $\mathrm{x}$ & & & & & \\
\hline Peterson (2015) & & & & & & & & & & $x$ \\
\hline Cárdenas-Rodrígues et al. (2015) & & & & & & & & & & $x$ \\
\hline Alexei (2015) & & & & & $x$ & & & $x$ & & \\
\hline Monk et al. (2015) & & & & & $\mathrm{x}$ & & & & & \\
\hline Holley (2015) & & & & & & & $\mathrm{x}$ & & & \\
\hline Miles (2015) & & & & & & & $\mathrm{x}$ & & & \\
\hline Scimeca and Labaree (2015) & $x$ & & & $x$ & & & & & & \\
\hline Engerman (2015) & & & & & & & $\mathrm{X}$ & & & \\
\hline Lygo-Baker et al. (2015) & & & & & & & & & & $x$ \\
\hline Vasconcelos (2015) & $x$ & & $x$ & & & & & & & \\
\hline Ventura and Lins (2014) & & & & & & & & & & $\mathrm{x}$ \\
\hline McCulloch (2014) & & & & $\mathrm{x}$ & & & & & $x$ & \\
\hline Bursztyn and Drummond (2014) & & & & & & & & & & $x$ \\
\hline Bossio et al. (2014) & & & $\mathrm{X}$ & $\mathrm{x}$ & & & & & & \\
\hline Fonsêca et al. (2014) & & & & & & & & & & $x$ \\
\hline Cesco et al. (2014) & & & & & & & & & & $x$ \\
\hline Strengers (2014) & $x$ & & & & & & & & & \\
\hline Oliva-Figueroa et al. (2014) & & & & $x$ & $x$ & & & & & \\
\hline MacDonnell (2014) & & & & & & & & & & $x$ \\
\hline Lee (2014) & & & & & & & & $x$ & & \\
\hline Mobley et al. (2014) & $x$ & $x$ & & & & & $x$ & & $x$ & \\
\hline Balon (2014) & $x$ & & & & & $x$ & & & & \\
\hline Duda (2014) & & & $x$ & & & & & & & \\
\hline Total & 15 & 11 & 8 & 11 & 9 & 6 & 4 & 7 & 8 & 11 \\
\hline
\end{tabular}


Brazilian Journal of Operations \& Production Management Volume 16, Número 1, 2019, pp. 113-125 DOI: 10.14488/BJOPM.2019.v16.n1.a11
Figure 2, which shows the frequency of subjects addressed by the selected authors, is presented below.

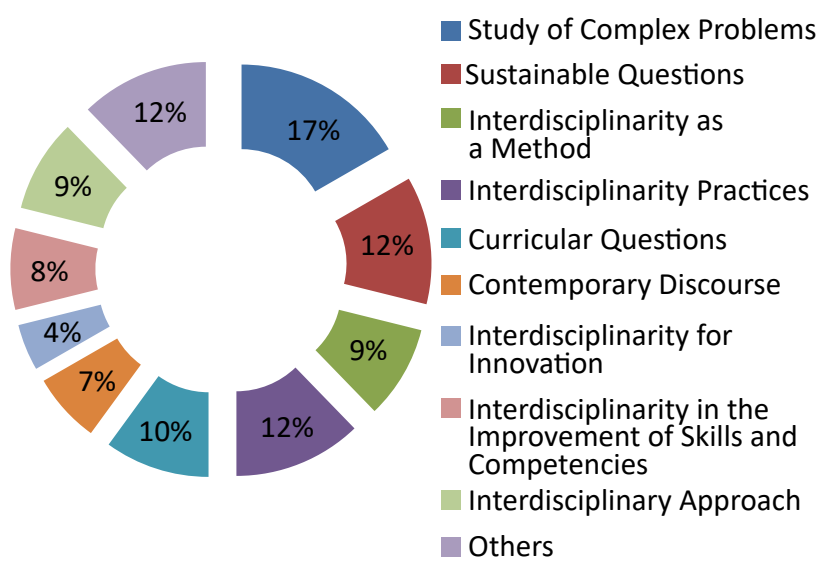

Figure 2. Frequency of subjects - Authors' own work (2018).

After analyzing the graph, the topic most frequently addressed by the authors about the importance of the study of Interdisciplinarity is the "Study of Complex Problems," with $16.7 \%$, followed by "Interdisciplinary Practices," "Sustainable Issues" and "Other," with $12.2 \%$ each. The first three subjects are closely linked to the need for a behavioral change in the educational approach of interdisciplinarity, as a field of complexity that can be internalized through practical experiences provided by a contemporary education, aiming at sustainability. The subjects of "Curricular Questions", "Interdisciplinarity as a Method", and "Interdisciplinary Approach" are factors that support the possible changes in formal curricula. A larger gap of study is found in the following subjects with "Interdisciplinarity in the Improvement of Skills and Competencies", with "Contemporary Discourse", with "Interdisciplinarity for Innovation" being the least frequently cited. These last items are presented as the consequences that may arise from interdisciplinarity as a science of training of a new reality of competencies and their applications in the impetus of innovations that are necessary for the survival of organizations in this society of knowledge and that must be sustainable.

\section{CONCLUSION}

This article reached the objective of performing a cross-sectional bibliographical analysis in order to identify the frontier of knowledge in the interface of Interdisciplinarity and Higher Education. To do so, the abstracts of articles found in the SCOPUS database were used with the keywords "Interdisciplinarity" and "higher education" in the titles, abstracts and keywords "articles", "review" and "article in press". The timeframe from 2014 to 2018 aimed to find what is new in this context.
Furthermore, through the analysis of the abstracts, the following subjects were identified: Study of Complex Problems; Sustainable Issues; Interdisciplinarity as a Method; Interdisciplinary Practices; Curricular Questions; Contemporary Discourse; Interdisciplinarity for Innovation; Interdisciplinarity in the Improvement of Skills and Competencies; Interdisciplinary Approach; and Others, which were later used to quantify the subjects cited by each of the authors.

Thus, it was verified that $12.2 \%$ of the authors report the practices to promote interdisciplinarity in higher education. Many authors seek to define what comprises interdisciplinarity and note the importance of practicing it at all levels of education. The studies point to the use of interdisciplinarity for a better sustainable development and in terms of how acting in an interdisciplinary way is intrinsic to the proposal of sustainability. The quantitative results show that there is a greater deficiency of studies aimed at the application of the interdisciplinary approach in the development of this aspect for the improvement of society. This is a challenge for contemporary researchers in all fields of knowledge.

\section{REFERENCES}

Alexei, K. (2015), Liberal arts and sciences in the Russian University education system. Voprosy Obrazovaniya, Vol. 2015. Available at: https://www.scopus.com/inward/record. uri?eid=2-s2.0-85017140722\&doi=10.17323\%2f1814-95452015-4-62-71\&partnerID=40\&md5=2b6d9205efd185ec3227 53f5bb20c17c (Retrieved: 10/20/2018).

Annan-Diab, F.; Molinari, C. (2017), "Interdisciplinarity: Interdisciplinarity: Practical approach to advancing education for sustainability and for the Sustainable Development Goals". The International Journal of Management Education, Vol. 15, No. 2, Part B. Available at: https://doi.org/10.1016/j. ijme.2017.03.006(Retrieved: 10/20/2018).

Balon, J. (2014), “How are ideas privatised? The Neoliberal regime of knowledge and its appropriation of the postmodern 'weltbild'." Sociologicky Casopis, Vol. 50, No. 5. Available at: https://doi.org/10.13060/00380288.2014.50.5.120 (Retrieved: 10/20/2018).

Barth, M.; Michelsen, G. (2013), "Learning for change: an educational contribution to sustainability science". Sustainability science, Vol. 8, No. 1. Available at: https://doi. org/10.1007/s11625-012-0181-5 (Retrieved: 10/20/2018).

Bossio, D.; Loch, B.; Schier, M.; Mazzolini, A. (2014), "A roadmap for forming successful interdisciplinary education research collaborations: a reflective approach". Higher Education Research and Development, Vol. 33. Available at: https://www.scopus.com/inward/record.uri?eid=2-s2.0-84896547087\&doi=10.1080\%2f07294360.2013.832167\&p artner $I D=40 \& m d 5=193 b f b e 8 d 5 e 8 c 254512 d 843 d 29 a 15 b f c$ (Retrieved: 10/20/2018). 
Bromham, L.; Dinnage, R.; Hua, X. (2016), "Interdisciplinary research has consistently lower funding success". Nature, Vol. 534. Available at: doi:10.1038/nature18315 (Retrieved: 10/20/2018).

Brooks, C. F. (2017), "Disciplinary convergence and interdisciplinary curricula for students in an information society". Innovations in Education and Teaching International, Vol. 54. Available at: https://www.scopus.com/inward/record. uri?eid=2-s2.0-84961209935\&doi $=10.1080 \% 2 f 14703297.20$ 16.1155470\&partnerID $=40 \& \mathrm{md} 5=\mathrm{fd} 1538 \mathrm{bf851c823407 \textrm {cda } 7}$ 2c3225e570 (Retrieved: 10/20/2018).

Brudermann, T.; Holländer, R.; Pastres, R.; Posch, A.; Schot, P. (2017), "Integrating interdisciplinarity and internationality in sustainable development education". GAIA, Vol. 26. Available at: https://www.scopus.com/inward/record.uri?eid=2-s2.0-85043387074\&doi=10.14512\%2fgaia.26.4.16\&partner ID=40\&md5=b4afb0ac33381ef6773305c25dafc2b7 (Retrieved: $10 / 20 / 2018)$.

Buekers, M.; Ibáñez-Gijón, J.; Morice, A.H.P.; Rao, G.; Mascret, N.; Laurin, J.; Montagne G. (2017), "Interdisciplinary Research: A Promising Approach to Investigate Elite Performance in Sports". Quest, Vol. 69. Available at: https://www.scopus. com/inward/record.uri?eid=2-s2.0-84966697339\&doi=10.1 080\%2f00336297.2016.1152982\& partnerlD $=40 \& \mathrm{md5}=618 \mathrm{f}$ b5bbdd972307f08d30b2740b9679 (Retrieved: 10/20/2018).

Bursztyn, M.; Drummond, J. (2014), "Sustainability science and the university: Pitfalls and bridges to interdisciplinarity". Environmental Education Research, Vol. 20. Available at: https://www.scopus.com/inward/record.uri?eid=2-s2.0$-84898544442 \&$ doi $=10.1080 \% 2 f 13504622.2013 .780587 \& p$ artnerID $=40 \& m d 5=1 e 274 b b e 96526 c 086 a 4 b 79 d 9 e e 59 c 34 c$ (Retrieved: 10/20/2018).

Cárdenas-Rodríguez, R.; Terrón-Caro, T.; Monreal-Gimeno, C. (2015), "An interdisciplinary or a multidisciplinary approach at the university level. Challenges for teaching coordination". Bordon, Vol. 67. Available at: https://www.scopus.com/inward/record.uri?eid=2-s2.0-84960854562\&doi $=10.13042 \% 2$ fBordon.2015.67309\&partnerID $=40 \& m d 5=02 c c 1 d f 978 b c d d b$ 5efaf2eebd27a3894 (Retrieved: 10/20/2018).

Causgrove, D.J.; Goodwin, D.; Bouffard, M. (2016), "Introduction: Reflexions on Interdisciplinarity in Adapted Physical Activity". Quest, Vol. 68, No. 1. Available at: http://dx.doi.org /10.1080/00336297.2015.1118390 (Retrieved: 10/20/2018).

Cesco, S.; Moreira, R.J.; Lima, E.D.F.N. (2014), "Interdisciplinarity, betweentheconceptandthepractice: A case study". Revista Brasileira de Ciências Sociais, Vol. 29. Available at: https://www.scopus.com/inward/record.uri?eid=2-s2.0$-84904490693 \&$ partnerl $=40 \&$ md5 $=07 f 3 d f c 6 f 5 f 35 f 2 c c 7 f f 91$ dfb4063a4c (Retrieved: 10/20/2018).

Chernetsova, E.V.; Maslova, E.G.; Salski, L. (2018), “Implementation of integrative approach in teaching American studies in institutions of higher education". Integration of Educa- tion, Vol. 22. Available at: https://www.scopus.com/inward/ record.uri?eid=2-s2.0-85045913381\&doi=10.15507\%2f1991$-9468.090 .022 .201801 .120-133 \&$ partnerlD $=40 \& \mathrm{md} 5=5 \mathrm{a} 257$ 40744ca50364d71500d1b9132ff (Retrieved: 10/20/2018).

Choi, B.C; PAK, A.W. (2006), "Multidisciplinarity, interdisciplinarity and transdisciplinarity in health research, services, education and policy: 1. Definitions, objectives, and evidence of effectiveness". Clinical and investigative medicine, Vol. 29, No. 6. Available at: https://www.ncbi.nlm.nih.gov/ pubmed/17330451(Retrieved: 10/20/2018).

Clark, S.G.; Wallace, R.L. (2015) Integration and Interdisciplinarity: Concepts, Frameworks, and Education. Policy Sciences. Vol. 48, No. 2. Available at: https://doi.org/10.1007/ s11077-015-9210-4 (Retrieved: 10/20/2018).

Correia, S.O.B.; Souza, A.V.M. (2018), "A pesquisa interdisciplinar no Programa de Pós-Graduação em Desenvolvimento e Meio Ambiente da Universidade Federal de Sergipe ". Desenvolvimento e Meio Ambiente, Vol. 45, availablefrom: http://dx.doi.org/10.5380/dma.v45i0.49284 (Retrieved: 10/20/2018).

Donina, D.; Seeber, M.; Paleari, S. (2017), "Inconsistencies in the governance of interdisciplinarity: The case of the Italian higher education system". Science and Public Policy, Vol. 44. Available at: https://www.scopus.com/inward/record. uri?eid=2-s2.0-85042565614\&doi=10.1093\%2fscipol\%2fscx0 19\&partner ID=40\&md5=b4b678a88a2771cd6b11eeaa5c11 $8 b 60$ (Retrieved: 10/20/2018).

Duda, I. (2014), "New researches of everyday life and socio - Cultural history of Yugoslav socialism". PovijesniPrilozi, Vol. 46. Available at: https://www.scopus.com/inward/record. uri?eid=2-s2.0-84977138669\& partnerID $=40 \& \mathrm{md} 5=5172 \mathrm{~b} 02$ 2c672ab5654bf03def3c8e5c7 (Retrieved: 10/20/2018).

Engerman, D.C. (2015), "The Pedagogical Purposes of Interdisciplinary Social Science: A View from Area Studies in the United States". Journal of the History of the Behavioral Sciences, Vol. 51. Available at: https://www.scopus.com/inward/ record.uri?eid $=2-s 2.0-84920901786 \&$ doi $=10.1002 \% 2$ fjhbs. 2 $1701 \&$ partner $I D=40 \& \mathrm{md} 5=$ fedd834c62a69d84cc67b579bd $7 f 4435$ (Retrieved: 10/20/2018).

Ferrer-Balas, D. et al. (2008), "An international comparative analysis of sustainability transformation across seven universities". International Journal of Sustainability in Higher Education, Vol. 9, No. 3. Available at: https://doi. org/10.1108/14676370810885907 (Retrieved: 10/20/2018).

Fiore, S. M. (2008), "Interdisciplinarity as teamwork: How the science of teams can inform team science". Small Group Research, Vol. 39, No. 3. Available at: https://doi. org/10.1177/1046496408317797 (Retrieved: 10/20/2018).

Fonsêca, G.S.; Junqueira, S.R.; Zilbovicius, C.; Araujo, M.E. (2014), "Education through work: Reorienting health care professionals' education". Interface: Communication, Health, 
Brazilian Journal of Operations \& Production Management

Volume 16, Número 1, 2019, pp. 113-125

DOI: 10.14488/BJOPM.2019.v16.n1.a11
Education, Vol. 18. Available at: https://www.scopus.com/ inward/record.uri?eid=2-s2.0-84906995498\&partnerID=4 0\&md5=efa2691fcb5095eb85b58e8330a4f9db (Retrieved: 10/20/2018).

Freitas, J.G.; Costa, H.G.; Ferraz, F.T. (2017), “Impacts of Lean Six Sigma over organizational sustainability: A survey study, Journal of Cleaner Production", Vol 156. Available at: https://doi.org/10.1016/j.jclepro.2017.04.054 (Retrieved: 10/20/2018).

Gasevic, D.; Kovanović, V.; Joksimović, S.; Siemens, G. (2014), "Where is research on massive open online courses headed? A data analysis of the MOOC Research Initiative". The International Review of Research in Open and Distributed Learning, Vol. 15, No. 5. Available at: http://www.irrodl. org/index.php/irrodl/article/view/1954/3111 (Retrieved: 10/20/2018).

Grierson, D.; Munro, K. (2018), "Transformative learning methods in interdisciplinary postgraduate education for sustainable development (ESD)". Archnet-IJAR, Vol. 12. Available at: https://www.scopus.com/inward/record.uri?eid=2-s2.0$-85044752203 \&$ doi $=10.26687 \% 2$ farchnet-ijar.v12i1.1430\&pa rtnerID=40\&md5=af9b29c94cad69a0bf4648d9530eafca（Retrieved: 10/20/2018).

Haapakorpi, A. (2018), "How multi/interdisciplinarity is actualised in work organisation with professional employees specialised in single disciplines: two case studies of the high-technology industry". Journal of Education and Work. Available at: https://www.scopus.com/inward/record.uri?eid=2-s2.0-85055130088\&doi=10.1080\%2f13639080.2018.1535 700\&partnerID $=40 \& \mathrm{md} 5=06291 \mathrm{e} 7 \mathrm{f} 88 \mathrm{e} 9 \mathrm{e} 746 \mathrm{e} 0 \mathrm{e} 55623 \mathrm{~b} 18$ 5 f048 (Retrieved: 10/20/2018).

Hannon, J.; Hocking, C.; Legge, K.; Lugg, A. (2018), “Sustaining interdisciplinary education: developing boundary crossing governance". Higher Education Research \& Development, Vol. 37, No. 7. Available at: https://doi.org/10.1080/07 294360.2018.1484706 (Retrieved: 10/20/2018).

Holley, K.A. (2015), "Doctoral education and the development of an interdisciplinary identity". Innovations in Education and Teaching International. Available at: https://www.scopus. com/inward/record.uri?eid=2-s2.0-84942985109\&doi=10.10 80\%2f14703297.2013.847796\& partnerID=40\&md5=686355 79107c3798911be11fcabebb71 (Retrieved: 10/20/2018).

Holt, R.E.; Woods, P.J.; Ferreira, A.S.A. et al. (2017), “Avoiding pitfalls in interdisciplinary education". Climate Research, Vol. 74. Available at: https://www.scopus.com/inward/record.uri?eid=2-s2.0-85044427082\&doi=10.3354\%2fcr01491 \&partnerID=40\&md5=dc03a54040b77fca4553e1552c14ebbf (Retrieved: 10/20/2018).

Houaiss, A. (2017), “Grande Dicionário Houaiss da língua portuguesa online". Available at: [http://houaiss.uol.com.br], - (Retrieved: 11/27/2018).
Kaittani, D.; Derri, V.; Kioumourtzoglou, E. (2016), “Interdisciplinary learning in education: A focus on physics and physical education". Sport Science, Vol. 9. Available at: https://www. scopus.com/inward/record.uri?eid=2-s2.0-84977138618\&pa rtnerID=40\&md5=49b4b2aee7c19984de58d6d3f744e1fa (Retrieved: 10/20/2018).

Kern, V.M.; Maldonado, M.U.; Freire, P.D.S.; Pacheco, R. C. D. S. (2011), "Construção da interdisciplinaridade para a inovação". In: Philippi JR, A.; Silva Neto, A. J. (Eds.). Interdisciplinaridade em Ciência, Tecnologia \& Inovação. Barueri, SP: Manole. p. 743-767.

Khoo, S.-M.; Haapakoski, J.; Hellstén, M.; Malone J. (2018), "Moving from interdisciplinary research to transdisciplinary educational ethics: Bridging epistemological differences in researching higher education internationalization(s)". European Educational Research Journal. Available at: https://www.scopus.com/inward/record.uri?eid=2-s2.0-85048774711\&doi=1 $0.1177 \% 2 f 1474904118781223 \&$ partnerID $=40 \& \mathrm{md} 5=53002 \mathrm{e}$ bf0eb7499a5d4b4267865762a7 (Retrieved: 10/20/2018).

Klassen, R.G. (2018), "Interdisciplinary education: a case study". European Journal of Engineering Education, Vol. 43, No. 6. Available at: https://doi.org/10.1080/03043797.2018. 1442417(Retrieved: 10/20/2018).

Klein, J.T.; Falk-Krzesinski, H.J. (2017), "Interdisciplinary and collaborative work: Framing promotion and tenure practices and policies". Research Policy, Vol. 46, No. 6. Available at: https://www.sciencedirect.com/science/article/pii/ S0048733317300446 (Retrieved: 10/20/2018).

Knewstubb, B.; Nicholas, H. (2017), "From model to methodology: developing an interdisciplinary methodology for exploring the learning-teaching nexus". International Journal of Research and Method in Education, Vol. 40. Available at: https://www.scopus.com/inward/record.uri?eid=2-s2.0$-85015962187 \&$ doi $=10.1080 \% 2 f 1743727 X .2017 .1301914 \&$ partnerID $=40 \& m d 5=8 d 3 b b b 28 d 71344 d d 7 f 96 f 3 b f 276 d 16 d 5$ (Retrieved: 10/20/2018).

Lee, A.W.S. (2014), "Faces vs. words: Interdisciplinary possibilities in the "ghosts" of Sunset Boulevard (1950)". International Journal of Literacies, Vol. 22. Available at: https://www. scopus.com/inward/record.uri?eid=2-s2.0-84937428253\&pa rtnerID=40\&md5=4b70472bf5dc73c5e6ac4f7c7aa9418b (Retrieved: 10/20/2018).

Leydesdorff, L.; Wagner, C.S.; Bornmann, L. (2018). “Betweenness and diversity in journal citation networks as measures of interdisciplinarity-A tribute to Eugene Garfield". Scientometrics, Vol. 114, No. 2. Available at: https://doi. org/10.1007/s11192-017-2528-2 (Retrieved: 10/20/2018).

Longhurst, R.; Jones, A. (2018). "Enhancing higher education curricula: A case study from the University of Waikato, New Zealand". London Review of Education, Vol. 16, No. 2. Available at: https://doi.org/10.18546/LRE.16.2.07(Retrieved: 10/20/2018). 
Lygo-Baker, S.; Kokotailo, P.K.; Young K.M. (2015), “Developing confidence in uncertainty: Conflicting roles of trainees as they become educators in veterinary and human medicine". Journal of Veterinary Medical Education, Vol. 42. Available at: https://www.scopus.com/inward/record.uri?eid=2-s2.0$-84948740253 \&$ doi $=10.3138 \% 2$ fjvme.1114-107R\&partnerl $\mathrm{D}=40 \& \mathrm{md5}=\mathrm{e} 597$ ecc4ac9d551dce6beedfe1729026 (Retrieved: 10/20/2018).

MacDonnell, J.A. (2014), “Enhancing our Understanding of Emancipatory Nursing: A Reflection on the Use of Critical Feminist Methodologies". Advances in Nursing Science, Vol. 37. Available at: https://www.scopus.com/inward/record. uri?eid=2-s2.0-84905910651\&doi=10.1097\%2fANS. 0000000 $000000038 \&$ partner $I D=40 \& m d 5=c d 4 f a f 9 d 29273944 b 87 a 5 b$ 024ea080f1 (Retrieved: 10/20/2018).

Macuch, R.S.; Dal Forno, L.F. (2017), "Learning Topics in Knowledge Management: An interdisciplinary perspective in the context of higher education". Espacios, Vol. 38. Available at: https://www.scopus.com/inward/record.uri?eid=2-s2.0$-85038630406 \&$ partnerID $=40 \& \mathrm{md5}=\mathrm{c} 39 \mathrm{~b} 7 \mathrm{e} 0397 \mathrm{~d} 0 \mathrm{ff} 151 \mathrm{fef0}$ 55fc5591214 (Retrieved: 10/20/2018).

McCulloch, G. (2014), "Interdisciplinarity in action: the Centre for Contemporary Cultural Studies, 1964-2002". Journal of Educational Administration and History, Vol. 46. Available at: https://www.scopus.com/inward/record.uri?eid=2-s2.0-84897106502\&doi=10.1080\%2f00220620.2014.889094 \&partnerID $=40 \&$ md5 $=$ ccf09e9d01940e0684c1a6a0eb516e $1 \mathrm{f}$ (Retrieved: 10/20/2018).

Miles, M.; Rainbird, S. (2015), "Evaluating interdisciplinary collaborative learning and assessment in the creative arts and humanities". Arts and Humanities in Higher Education, Vol. 14. Available at: https://www.scopus.com/inward/record. uri?eid=2-s2.0-84942093935\&doi=10.1177\%2f14740222145 61759\&partnerID $=40 \& m d 5=19 \mathrm{e} 423869 \mathrm{~b} 61 \mathrm{f} 8268 \mathrm{a} 3 \mathrm{e} 8 \mathrm{bb} 15 \mathrm{c}$ 15feeb (Retrieved: 10/20/2018).

Milić, D. C.; Martinović, G.; Ferčec, I. (2018), "Analysis and proposals for improving knowledge and skills in engineering aimed at reducing unemployment". TehnickiVjesnik, Vol. 25. Available at: https://www.scopus.com/inward/ record.uri?eid=2-s2.0-85041912184\&doi $=10.17559 \% 2 \mathrm{fTV}$ -20161107202808 \& partnerID $=40 \& m d 5=f 80291 a 23 b c b 4838$ 61398130350992ab (Retrieved: 10/20/2018).

Mobley, C.; Lee, C.; Morse, J.C.; Allen, J.; Murphy, C. (2014), "Learning about sustainability: An interdisciplinary graduate seminar in biocomplexity". International Journal of Sustainability in Higher Education, Vol. 15. Available at: https://www.scopus.com/inward/record.uri?eid=2-s2.084890339041\&doi=10.1108\%2fIJSHE-09-2011-0063\&partner $\mathrm{ID}=40 \& \mathrm{md} 5=\mathrm{cde} 8899118 \mathrm{~b} 9 f 65 f 2935068 \mathrm{eaOdb} 13$ ea (Retrieved: $10 / 20 / 2018$ ).

Molderez, I.; Fonseca, E. (2018), "The efficacy of real-world experiences and service learning for fostering com- petences for sustainable development in higher education". Journal of Cleaner Production, Vol. 172. Available at: https://www.scopus.com/inward/record.uri?eid=2-s2.0$-85038844862 \&$ doi $=10.1016 \% 2$ fj.jclepro.2017.04.062\&partn erID $=40 \& m d 5=42 f 7 c 111 f 8 a 239 a 3 a e 7 a c 019 a 2 a f c 640$ (Retrieved: $10 / 20 / 2018$ ).

Monk, N.; McDonald, S.; Pasfield-Neofitou, S.; Lindgren, M. (2015), "Portal pedagogy: From interdisciplinarity and internationalization to transdisciplinarity and transnationalization". London Review of Education, Vol. 13. Available at: https://www.scopus.com/inward/record.uri?eid=2-s2.0$-84994812872 \&$ doi $=10.18546 \% 2 f L R E .13 .3 .10$ \&partnerID $=4$ 0\&md5=9b490af2e96cdbabda5546b7f94a5edb (Retrieved: 10/20/2018).

Morillo, F.; Bordons, M.; Gómez, I. (2003), "Interdisciplinarity in science: A tentative typology of disciplines and research areas". Journal of the Association for Information Science and Technology, Vol. 54, No. 13. Available at: https://onlinelibrary.wiley.com/doi/full/10.1002/asi.10326 (Retrieved: 10/20/2018).

Mossman, A.P. (2018), "Retrofitting the ivory tower: Engaging global sustainability challenges through interdisciplinary problem-oriented education, research, and partnerships in U.S. higher education". Journal of Higher Education Outreach and Engagement, Vol. 22. Available at: https://www.scopus. $\mathrm{com} /$ inward/record.uri?eid=2-s2.0-85044766648\&partnerl $\mathrm{D}=40$ \& md5=07606f66827bb231de91382616c16eee (Retrieved: $10 / 20 / 2018)$.

Murray, J. (2018) "Student-led action for sustainability in higher education: a literature review", International Journal of Sustainability in Higher Education, Vol. 19,No. 6,available at: https://doi.org/10.1108/IJSHE-09-2017-0164(Retrieved: 10/20/2018).

Nanni, F.; Dietz, L.; Ponzetto, S.P. (2018), “Toward a computational history of universities: Evaluating text mining methods for interdisciplinarity detection from PhD dissertation abstracts". Digital Scholarship in the Humanities, Vol. 33. Available at: https://www.scopus.com/inward/record.uri?eid=2-s2.0-85055341288\&doi=10.1093\%2fLLC\%2fFOX062\&partne rID $=40 \& m d 5=7 d c e 6 c 45 c f 72932684 c b 516 c 210713 b 4$ (Retrieved: $10 / 20 / 2018)$.

Oliva-Figueroa, I.; Koch-Ewertz, T.; Quintero-Tapia, J. (2014), "Interdisciplinary/transdisciplinary and the university: Patterns of Disciplinary mobility and interactivity". Magis, Vol. 6. Available at: https://www.scopus.com/inward/record. uri?eid=2-s2.0-84905401028\&doi=10.11144\%2fJaveriana. M6-13.ITUP\&partnerID=40\&md5=5ac10336427b343c23ff63 17d3f1bfdb (Retrieved: 10/20/2018).

Ouellet Dallaire, C.; Trincsi, K.; Ward, M.K.; Harris, L.I.; Jarvis, L.; Dryden, R.L.; MacDonald, G.K. (2018), “Creating space for sustainability literacy: the case of student-centered symposia". International Journal of Sustainability in Higher Educa- 
Brazilian Journal of Operations \& Production Management

Volume 16, Número 1, 2019, pp. 113-125

DOI: 10.14488/BJOPM.2019.v16.n1.a11 tion, Vol. 19. Available at: https://www.scopus.com/inward/ record. uri?eid $=2-$ s2.0-85045833814\&doi $=10.1108 \% 2 \mathrm{fIJSHE}-$ 08-2017-0126\&partnerID =40\&md5=16b0c2ef560d4c6f01b2 a482b10c45a0 (Retrieved: 10/20/2018).

Pereira, S.C.L.; Macedo, T.R.; Santos L.C.; Alves, C.R.L. (2018), "The contribution of the Educational Program for Health Work in "being a SUS professional"', Mundo da Saude, Vol. 42, No.3. Available at: https://doi.org/10.15343/0104-7809.20184203569586(Retrieved: 10/20/2018).

Peterson, J.F. (2015), "Creative leadership for interdisciplinary education". International Journal of Educational Organization and Leadership, Vol. 22. Available at: https://www.scopus.com/inward/record.uri?eid=2-s2.0$-84981743127 \&$ doi $=10.18848 \% 2 f 2329-1656 \% 2 f C G P \% 2 f v 22 i$ 04\%2f48516\&partnerID=40\&md5=94671c8cd3c0ae8add3a7 e9a537f278f (Retrieved: 10/20/2018).

Pinto, L.B.; Bianchim V.R.; Oliveira, S.C. (2017), "The establishment of a proposal methodology interdisciplinary for analysis of a case study oriented development. Espacios, Vol. 38. Available at: https://www.scopus.com/inward/record. uri?eid=2-s2.0-85018771610\&partnerID=40\&md5=8aa3934 9cfb5c5be0a3c3b01d728f1bd (Retrieved: 10/20/2018).

Power, E.J.; Handley J. (2017), “A best-practice model for integrating interdisciplinarity into the higher education student experience". Studies in Higher Education. Available at: https://www.scopus.com/inward/record.uri?eid=2-s2.0$-85031998739 \&$ doi=10.1080\%2f03075079.2017.1389876\& partner ID $=40 \& \mathrm{md} 5=\mathrm{b} 61 \mathrm{e} 502853 \mathrm{~d} 29 \mathrm{c} 53958 \mathrm{~b} 7441 \mathrm{ed} 3 \mathrm{aa} 8 \mathrm{ff}$ (Retrieved: 10/20/2018).

Raynaut, C. (2011), "Interdisciplinaridade: mundo contemporâneo, complexidade e desafios à produção e à aplicação de conhecimentos". In: PHILIPPI JR, A.; SILVA NETO, A. J. (Eds.). Interdisciplinaridade em Ciência, Tecnologia \& Inovação. Barueri, SP: Manole. pp. 69-105, 2011

Raynaut, C. (2014), “Os desafios contemporâneos da produção do conhecimento: o apelo para interdisciplinaridade". INTERthesis, Vol. 11, No. 1. Available at: http:// dx.doi.org/10.5007/1807-1384.2014v11n1p1(Retrieved: 10/20/2018).

Rhoten, D.; Pfirman, S. (2007), "Women in interdisciplinary science: Exploring preferences and consequences". Research policy, Vol. 36, No. 1. Available at: https://www.sciencedirect. com/science/article/pii/S0048733306001338 (Retrieved: 10/20/2018).

Ribeiro, F.M. (2016), "Interdisciplinarity in ferment: The role of knowledge networks and department affiliation". Technological Forecasting and Social Change, Vol. 113. Available at: https://www.scopus.com/inward/record.uri?eid=2-s2.0$-84940706318 \&$ doi=10.1016\%2fj.techfore.2015.07.021\&part nerlD=40\&md5=5ea9676cd50b30c84f44497f2d5d6432 (Retrieved: 10/20/2018).
Richter, D.M.; Paretti, M.C. (2009), “Identifying barriers to and outcomes of interdisciplinarity in the engineering classroom". European Journal of Engineering Education, Vol. 34, No. 1. Available at: https://www.tandfonline.com/doi/ abs/10.1080/03043790802710185 (Retrieved: 10/20/2018).

Schäfke, W.;Díaz-Asensio, J.A.M.;Hvidt, M.S. (2018)“Socialisation to interdisciplinary legal education: an empirical assessment". The Law Teacher, Vol. 52, No. 3. Available at: https://doi.org/10.1080/03069400.2017.1415080(Retrieved: 10/20/2018).

Scimeca, R.; Labaree, R.V. (2015), "Synoptic reference: Introducing a polymathic approach to reference services". Library Trends, Vol. 63. Available at: https://www.scopus.com/ inward/record.uri?eid=2-s2.0-84928017651\&doi=10.1353\%2 flib. 2015.0005\&partnerID=40\&md5=f6a0e522b10a56e87dd a7061441f3dc8 (Retrieved: 10/20/2018).

Sclater, M.; Lally, V. (2018), "Interdisciplinarity and technology-enhanced learning: Reflections from art and design and educational perspectives". Research in Comparative and International Education, Vol. 13. Available at: https://www.scopus.com/inward/record.uri?eid=2-s2.0-85047089899\&doi=1 $0.1177 \% 2 f 1745499918768111$ \&partnerlD $=40 \&$ md5=d0c717 513be1eda56e446d61da392d54 (Retrieved: 10/20/2018).

Self, J.A.; Baek J.S. (2017), "Interdisciplinarity in design education: understanding the undergraduate student experience". International Journal of Technology and Design Education, Vol. 27. Available at: https://www.scopus.com/inward/record.uri?eid=2-s2.0-84955615694\&doi=10.1007\%2fs10798016-9355-2\&partnerID=40\&md5=ed001f50e8e9f1d29207c1 58f9f7700c (Retrieved: 10/20/2018).

Shandas, V.; Brown, S.E. (2016), “An Empirical Assessment of Interdisciplinarity: Perspectives from Graduate Students and Program Administrators". Innovative Higher Education, Vol. 41. Available at: https://www.scopus.com/inward/record.uri?eid=2-s2.0-84958748468\&doi=10.1007\%2fs10755016-9362-y\&partnerID=40\&md5=430efa8b51aea162b1d5ec e46be8f33f (Retrieved: 10/20/2018).

Sparke M. (2018), Textbooks as opportunities for interdisciplinarity and planetarity. Area, Vol. 50. Available at: https://www.scopus.com/inward/record.uri?eid=2-s2.0$-85042495035 \&$ doi $=10.1111 \% 2$ farea $.12402 \&$ partner ID $=40$ \&md5=6265d4b486b6a1b6c36a9c865ef18a7b (Retrieved: 10/20/2018).

Steiner, G.; Posch, A. (2006), "Higher education for sustainability by means of transdisciplinary case studies: an innovative approach for solving complex, real-world problems". Journal of Cleaner Production, Vol. 14, No. 9. Available at: https://www.sciencedirect.com/science/article/pii/ S0959652606000242 (Retrieved: 10/20/2018).

Strengers, Y.A.-A. (2014), "Interdisciplinarity and industry collaboration in doctoral candidature: tensions within and between discourses". Studies in Higher Education, Vol. 
39. Available at: https://www.scopus.com/inward/record. uri?eid=2-s2.0-84901333856\&doi=10.1080\%2f03075079.20 12.709498\&partner ID $=40 \& \mathrm{md} 5=83 \mathrm{a} 541 \mathrm{c} 7 \mathrm{~b} 0 \mathrm{dc} 6 \mathrm{ffOe} 98 \mathrm{dd} 64$ 5006c7bd9 (Retrieved: 10/20/2018).

Szostak, R. (2016), "Interdisciplinary Best Practices for Adapted Physical Activity". Quest, Vol. 68. Available at: https://www.scopus.com/inward/record.uri?eid=2-s2.0$-84956879043 \&$ doi $=10.1080 \% 2 f 00336297.2015 .1117001 \&$ partnerID $=40 \& m d 5=655784354 f 4618 f 4 d 9579391 \mathrm{cbb} 5 \mathrm{c} 85 \mathrm{c}$ (Retrieved: 10/20/2018).

Tarrant, S.P.; Thiele, L.P. (2017), "Enhancing and promoting interdisciplinarity in higher education". Journal of Environmental Studies and Sciences, Vol. 7. Available at: https://www.scopus.com/inward/record.uri?eid=2-s2.085017512902\&doi=10.1007\%2fs13412-016-0402-9\&partner ID $=40 \&$ md5=bad4126d6e77454cd2818c1230feb159 (Retrieved: $10 / 20 / 2018$ ).

Toassi, R.F.C.; Lewgoy, A.M.B. (2016), "Integrated health practices I: An innovative experience through inter-curricular integration and interdisciplinarity". Interface: Communication, Health, Education, Vol. 20. Available at: https://www.scopus.com/inward/record.uri?eid=2-s2.0-84960497232\&doi=10.1590\%2f1807-57622015.0123\&part nerlD $=40 \&$ md5 $=$ cc4adad87ba7f6dea7000f903bf8e266 (Retrieved: 10/20/2018).

Ülkü, M.A.; Karkowski, A.M., Lahm, T.D. (2018), “Perspectives on interdisciplinary undergraduate research". Educational Studies, Vol. 44. Available at: https://www.scopus.com/ inward/record. uri?eid=2-s2.0-85022085904\&doi $=10.1080 \% 2$ f03055698.2017.1347497\& partnerID=40\&md5=285b4e8ae9 176fa2bea5ccbcdcdd662d (Retrieved: 10/20/2018).

Vasconcelos, F.A.G. (2015), "The construction of scientific knowledge in food and nutrition: Analysis of dissertations and theses in the Brazilian post-graduation programs in nutrition". Revista de Nutrição, Vol. 28. Available at: https://www.scopus.com/inward/record. uri?eid=2-s2.0-84923063368\&doi $=10.1590 \% 2 \mathrm{f} 1415$ $-52732015000100001 \&$ partnerID $=40 \& m d 5=4 e 2 a d 2736 e e d 9$ 8abe72d86cf81495cd4 (Retrieved: 10/20/2018).

Ventura, D.F.F.; Lins, M.A.T. (2014), “Higher education and complexity: Disciplinary integration in the field of internatio- nal relations". Cadernos de Pesquisa, Vol. 44, No. 151. Available at: http://dx.doi.org/10.1590/198053142780 (Retrieved: 10/20/2018).

Vienni Baptista, B.; Vasen, F.; Villa Soto, J.C. (2018), “Interdisciplinary Centers in Latin American Universities: The Challenges of Institutionalization". Higher Education Policy. Available at: https://www.scopus.com/inward/record. uri?eid=2-s2.0-85046041651\&doi $=10.1057 \% 2 \mathrm{fs} 41307-018$ 0092-x\&partnerID=40\& md5=0d9cf6941150045420ef1dd5c3 bb3f56 (Retrieved: 10/20/2018).

Weidner, E.W. (1973), "Interdisciplinarity and higher education". International Journal of Environmental Studies, Vol. 5, No. 1-4. Available at: https://www.tandfonline.com/doi/ abs/10.1080/00207237308709610 (Retrieved: 10/20/2018).

Widener, J.M.; Gliedt, T.; Tziganuk, A. (2016), "Assessing sustainability teaching and learning in geography education". International Journal of Sustainability in Higher Education, Vol. 17. Available at: https://www.scopus.com/inward/record.uri?eid=2-s2.0-84986218360\&doi=10.1108\%2fIJSHE-032015-0050\&partnerID=40\&md5=37ea3999998d24985443ca 990e4b578c (Retrieved: 10/20/2018).

Wood, B.E.; Cornforth, S.; Beals, F.; Taylor, M.; Tallon, R. (2016), "Sustainability champions? Academic identities and sustainability curricula in higher education". International Journal of Sustainability in Higher Education, Vol. 17. Available at: https://www.scopus.com/inward/record.uri?eid=2-s2.084978159531\&doi=10.1108\%2fIJSHE-12-2014-0171\&partne $\mathrm{rID}=40 \& \mathrm{md} 5=0 \mathrm{de} 88 \mathrm{f} 79 \mathrm{ff} 46 \mathrm{ed} 1688 \mathrm{e} 8 \mathrm{e} 1 \mathrm{a} 3275 \mathrm{a} 2 \mathrm{ba0}$ (Retrieved: $10 / 20 / 2018$ ).

Yarime, M.; Trencher, G.; Mino, T.; Scholz, R.W.; Olsson, L.; Ness, B. et al. (2012). "Establishing sustainability science in higher education institutions: towards an integration of academic development, institutionalization, and stakeholder collaborations". Sustainability Science, Vol. 7, No. 1. Available at: https://doi.org/10.1007/s11625-012-0157-5(Retrieved: 10/20/2018).

Zverev, I.D. (1975), "Interdisciplinarity in School Education in the USSR". Prospects, Vol. 51, No. 4. Available at: https:// link.springer.com/article/10.1007/BF02220085 (Retrieved: 10/20/2018).

Received: 26 Nov 2018

Approved: 15 Dec 2018

DOI: 10.14488/BJOPM.2019.v16.n1.a11

How to cite: Marins, B. V. S.; Ramos, H. C.; Ferreira, G. S. et al. (2019), "Interdisciplinarity in Higher Education: A Cross-Sectional Analysis of the Literature in the period 2014-2018", Brazilian Journal of Operations \& Production Management, Vol. 16, No. 1, pp. 113-125, available from: https://bjopm.emnuvens.com.br/bjopm/article/ view/733 (access year month day). 